4 Feorino PM, Humphrey D, Hochberg F, Chilicote R. Mononucleosisassociated subacute sclerosing panencephalitis. Lancet 1975;ii:530-2.

${ }^{5}$ Peterslund NA, Pedersen B. Liquor: serum quotients of IgG and albumin in patients with meningism, meningitis, and multiple sclerosis. Acto Neurol Scand 1982;66:25-33.

(Accepted 27 October 1982)

Institute of Cancer Research, Radiumstationen, DK-8000 Aarhus C, Denmark

MADS MELBYE, medical student

PETER EBBESEN, MD, head of institute

Department of Infectious Diseases, Rigshospitalet, DK-2100 Copenhagen $\phi$, Denmark

NIELS JACOBSEN, MD, registrar

Ornithosis Department, Statens Seruminstitut, DK-2300 Copenhagen S, Denmark

CARL H MORDHORST, MD, head of department

\section{Association between alcohol consumption and adult pedestrians who sustain injuries in road traffic accidents}

We studied 50 consecutive pedestrians who were victims of road traffic accidents and 50 controls to assess the influence of alcohol in pedestrians involved in accidents and on the severity of the injuries sustained.

\section{Subjects, methods, and results}

Blood alcohol equivalents were obtained from breath samples with a Lion Alcolmeter. In eight patients with severe injuries the alcohol concentration was estimated from blood samples. One week after the accident, and within 30 minutes of the time of the accident, controls were obtained by approaching the first passer by of the same sex and roughly the same age as the patient at the site where the accident had occurred.

The patient and control groups both comprised 27 men and 23 women. Patients were aged 13-72 years (median 26 years). Differences in age between patients and controls were small (mean $0 \cdot 4$, SD $3 \cdot 0$ years). Differences between the time of testing patients and their matched controls ranged from 0 to 45 minutes (median 10 minutes). On 46 occasions the first person approached to serve as a control agreed to give a breath specimen. The mean blood alcohol concentration in patients who had been drinking was $36.9 \mathrm{mmol} / 1$ (170 mg $100 \mathrm{ml}$ ) (range $13 \cdot 0-73.8 \mathrm{mmol} / 1(60-340 \mathrm{mg} / 100 \mathrm{ml})$ ) and in controls who had been drinking $20.0 \mathrm{mmol} / 1(92 \mathrm{mg} / 100 \mathrm{ml}$ ) (range $6 \cdot 5-39 \cdot 1 \mathrm{mmol} / \mathrm{l}$ $(30-180 \mathrm{mg} / 100 \mathrm{ml})$ ).

Alcohol was not detected in both patient and control in 27 of the patientcontrol pairs and was detected in both subjects in 12 pairs. In the remaining 11 pairs the patients yielded a positive result on blood alcohol testing and the controls a negative result. McNemar's test confirmed that patients were more likely to have been drinking $\left(\chi^{2}=9 \cdot 1, \mathrm{df}=1, \mathrm{p}=0.003\right)$. These figures give a lower $95 \%$ confidence limit of 2.5 for the relative risk of a pedestrian who has been drinking being involved in an accident.

Distribution of patients and controls by blood alcohol concentration and distribution of patients by injury severity score (ISS) and presence or absence of alcohol

\begin{tabular}{|c|c|c|c|}
\hline & No alcohol & $\begin{array}{c}\text { Alcohol } \\
0 \cdot 2-17 \cdot 4 \mathrm{mmol} / 1\end{array}$ & $\begin{array}{c}\text { Alcohol } \\
>17 \cdot 4 \mathrm{mmol} / 1\end{array}$ \\
\hline $\begin{array}{l}\text { Patients } \\
\text { Controls }\end{array}$ & $\begin{array}{l}27 \\
38\end{array}$ & $\begin{array}{l}5 \\
5\end{array}$ & $\begin{array}{r}18 \\
7\end{array}$ \\
\hline Relative risk & 1 & $1 \cdot 4$ & $3 \cdot 6$ \\
\hline $\begin{array}{l}\text { Severity of injury: } \\
\text { Mild (ISS 1-9) } \\
\text { Moderate (ISS 10-19) } \\
\text { Severe (ISS 20+) }\end{array}$ & $\begin{array}{r}24 \\
3\end{array}$ & 1 & \\
\hline
\end{tabular}

Conversion: SI to traditional units-Alcohol: $1 \mathrm{mmol} / 1 \approx 4.6 \mathrm{mg} / 100 \mathrm{ml}$.
The table shows the distribution of patients and controls according to the blood alcohol concentration, ignoring the matched pairs. From these figures an estimate of the relative risk of a pedestrian with a blood alcohol concentration of over $17.4 \mathrm{mmol} / \mathrm{l}(80 \mathrm{mg} / 100 \mathrm{ml})$ being involved in an accident is 3.6. The table also shows the injury severity score $^{1}$ of the patients against the presence or absence of alcohol in the blood. Comparison of the mildly injured patients with those moderately and severely injured yielded a positive association between alcohol concentration and more severe injury $\left(\chi^{2}=8 \cdot 1, \mathrm{df}=1, \mathrm{p}=0.004\right)$.

\section{Comment}

Crompton's recent survey² of blood alcohol concentrations in 208 people who died in road accidents is difficult to evaluate because of the absence of controls. We have found only three previous studies of alcohol concentrations in pedestrians in which controls were used. Two were based on fatal accidents to pedestrians. Haddon et al studied 20 pedestrians who died within six hours after their accidents. Comparison with controls, matched by site, gave an estimated relative risk of 18 for pedestrians with a blood alcohol concentration of $21 \cdot 7$ mmol or more $/ 1(>100 \mathrm{mg} / 100 \mathrm{ml})$. Clayton et al ${ }^{4}$ compared 344 victims who died and 1118 controls. Their figures give a relative risk of having a fatal accident of 4.6 for pedestrians with a blood alcohol concentration of $17.4 \mathrm{mmol}$ or more $/ 1(80 \mathrm{mg} / 100 \mathrm{ml})$.

Honkanen et $\mathrm{l}^{5}$ reported a controlled study of live patients, of whom 313 slipped and fell and 28 were pedestrian victims of road accidents. The relative risk of slipping and falling was 29 for a blood alcohol concentration of $45.6 \mathrm{mmol} / 1(210 \mathrm{mg} / 100 \mathrm{ml})$; that of being involved in a pedestrian accident was estimated to be 10 if alcoho was detected in the blood.

Our controls were well matched for age, sex, time of day, day of week, and season of year. We do not believe that the association between blood alcohol concentration and a high injury severity score has been previously reported. Our study confirms the central finding of the three case-control studies reported above that there is a strong positive association between blood alcohol concentrations and road accidents to pedestrians.

Baker SP, O'Neill B, Haddon W, Long WB. The injury severity score. A method for describing patients with multiple injuries and evaluating emergency care. $\mathcal{F}$ Trauma 1974;14:187.

- Crompton MR. Alcohol and fatal road traffic accidents. Medicine, Science and the Law $1982 ; 22: 189-94$

${ }^{3}$ Haddon W, Valien P, McCarrol JR, Umberger CJ. A controlled investigation of the characteristics of adult pedestrians fatally injured by motor vehicles in Manhattan. F Chron Dis 1961;14:655-78.

${ }^{1}$ Clayton AB, Booth AC, McCarthy PE. A controlled study of the role of alcohol in fatal adult pedestrian accidents. (Supplementary report 332 .) Crowthorne, Berkshire: Transport and Road Research Laboratory, 1977.

'Honkanen R, Ertarna L, Kuosmanen P, Linnoila M, Visari T. A casecontrol study on alcohol as a risk factor in pedestrian accidents. In Mattila M, ed. Alcohol, drugs and driving. Basle: Karger, 1976.

(Accepted 16 November 1982)

Musgrove Park Hospital, Belfast

S T IRWIN, FRCS, orthopaedic registrar

Queen's University, Belfast

C C PATTERSON, MSC, lecturer in medical statistics

Accident and Emergency Department, Royal Victoria Hospital, Belfast

W H RUTHERFORD, OBE, FRCS, consultant

\section{Correction}

Effects of amiodarone in thyrotoxicosis

We regret that two errors occurred in this article by Dr J Sheldon (22 January, p 267). Reference 3 should have read: Jaggarao NSV, Sheldon J Grundy EN, Vincent R, Chamberlain DA. The effects of amiodarone on thyroid function. Postgrad Med f 1982;58:693-6. The last paragraph of the Comment should have read: "Thus amiodarone controls thyrotoxicosis clinically and biochemically but has no advantages over equivalent doses of iodine except for its antiarrhythmic effects, and it may delay subsequen control by carbimazole.' 